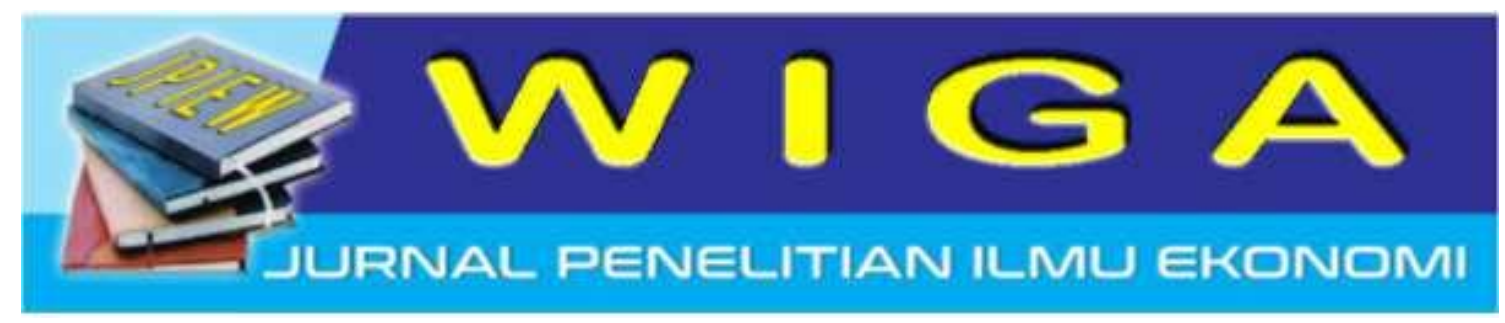

\title{
Kondisi Lingkungan Pekerjaan Sebagai Ukuran Kesetiaan Pada Organisasi
}

\author{
Riza Bahtiar Sulistyan \\ STIE Widya Gama Lumajang \\ rizabahtiars@gmail.com
}

\begin{abstract}
Abstrak
Kondisi lingkungan pekerjaan yang baik dapat mendorong karyawan dari dalam dirinya dan akan meningkatkan komitmen karyawan pada organisasi. Penelitian ini bertujuan untuk menguji model dari kondisi lingkungan pekerjaan yang baik dalam meningkatkan komitmen karyawan pada organisasi, baik secara langsung maupun tidak langsung melalui dorongan yang ada dalam diri karyawan. Terdapat 41 karyawan yang bersedia dijadikan responden. Metode analisis yang digunakan berupa Partial Least Square (PLS). Hasil penelitian menunjukkan bahwa kondisi lingkungan pekerjaan yang baik dapat mendorong karyawan dari dalam dirinya akan meningkatkan komitmen karyawan pada organisasi. Hal terpenting adalah memperhatikan dorongan dalam diri agar komitmen karyawan tetap tinggi.
\end{abstract}

Kata Kunci : Kondisi Lingkungan Pekerjaan, Dorongan dari dalam diri, Komitmen Karyawan

\section{Abstract}

Good working environment conditions can encourage employees from within and will increase employees' commitment to the organization. This study aims to test the model of good working environment conditions in increasing the commitment of employees to the organization, directly or indirectly through the encouragement that is in the employees. There are 41 employees willing to be respondents. The analysis method used is Partial Least Square (PLS). The results show that good working environment conditions can encourage employees from within themselves will increase the commitment of employees to the organization. The most important thing is to pay attention to the inner drive to keep high employee commitments.

Keywords: Working Environment Conditions, Encouragement from Within, Employee Commitment

\section{Pendahuluan}

Dalam sebuah organisasi, baik organisasi pemerintah maupun swasta harus mampu menjaga agar sumber daya manusianya memiliki kinerja yang tinggi. Untuk mempertahankan kinerja tidaklah mudah, harus diimbangi dengan beberapa faktor-faktor yang 
dapat meningkatkan kinerja. Karyawan yang mempunyai kinerja rendah, biasanya dipengaruhi beberapa faktor dan nantinya akan berimbas pada faktor-faktor yang lain seperti kurang terdorongnya karyawan tersebut dalam menyelesaikan pekerjaan. Namun tidak hanya itu, adanya kondisi lingkungan pekerjaan yang tidak sesuai dengan apa yang diharapkan juga bisa berdampak pada tingkat kesetiaan karyawan tersebut pada organisasi. Kondisi lingkungan yang baik diharapkan bisa mendorong seorang karyawan untuk tetap tinggal pada sebuah organisasi. Sehingga dengan kondisi lingkungan yang baik nanti diharapkan apa yang menjadi tujuan organisasi bisa tercapai. Nantinya kondisi lingkungan tersebut dapat mendorong karyawan secara pribadi dalam menciptakan komitmen kepada organisasi.

Kondisi lingkungan mencakup semua keadaan atau tempat yang ada dalam sebuah organisasi. Kondisi lingkungan tidak semua berbentuk fisik, namun ada juga yang non fisik seperti hubungan antar karyawan (Nitisemito, 2002; Sedarmayanti, 2011). Beberapa peneliti yang telah berhasil membuktikan keterkaitan kondisi dari lingkungan pekerjaan yang akan mendorong dari dalam diri seorang karayawan dan meningkatkan komitmen dari karyawan tersebut terhadap organisasi (Ushie et al., 2015; Driskell et al., 2017). Adapun dalam kondisi lingkungan yang tidak seimbang mempengaruhi tingkat komitmen afektif karyawan (Waldkirch et al., 2017).

Dorongan yang timbul dalam diri seseorang dapat menjadi tolok ukur dimana seorang karyawan bersedia melaksanakan tugas-tugas yang diberikan. Semua aktivitas yang dilakukan oleh seseorang pasti memiliki suatu faktor pendorong, baik dorongan yang timbul dari dalam diri seorang tersebut maupun dari luar (Sutrisno, 2017). Beberapa kajian terkait dengan kondisi lingkungan pekerjaan dapat mendorong seseorang dari dalam dirinya. Tidak hanya dalam bentuk imbalan atas apa yang telah dihasilkan, tetapi kondisi dari lingkungan pekerjaan juga dapat mendorong seseorang untuk tetap tinggal di sebuah organisasi (James dan Simmons, 2007; Mattson et al., 2014; Katz, 2015). Disisi lain terdapat kondisi lingkungan yang tidak memiliki peran penting dalam mendorong seorang dalam melakukan pekerjaan (Sulistyan, 2017).

Kondisi lingkungan yang menyangkut hubungan dengan sesama karyawan, seperti adanya konflik nantinya akan mempengaruhi tingkat psikologi dan dorongan dari dalam diri karyawan untuk tetap berkomitmen menurun (Neill dan Mclarnon, 2017). Kehidupan dalam pekerjaan yang seimbang mempunyai hubungan yang erat dikaitkan dengan komitmen karyawan. Adanya keseimbangan dalam kehidupan pekerjaan, hal ini menyangkut kondisi lingkungan yang ada di dalam pekerjaan penting dalam pengembangan komitmen karyawan (Azem dan Akhtar, 2014). Komitmen merupakan ikatan secara psikologis seorang karyawan pada organisasi ditandai dengan adaya kepercayaan pada tujuan organisasi, adanya kemauan berusaha dengan sungguh-sungguh dan keinginan untuk tetap setia dan memelihara keanggotaannya dalam organisasi (Luthans, 2002; Robbins, 2015).

Seperti halnya pada organisasi lain yang ada di Indonesia, karyawan kontrak yang ada di lapangan pada instansi Unit Pelaksana Teknis Pengelolaan Sumber Daya Air di Lumajang menjadi keunikan tersendiri terkait dengan kondisi lingkungan 
pekerjaan yang nantinya dapat dijadikan tolok ukur kesetiaan pada organisasi. Dilihat dari kondisi lingkungan pekerjaan tentu dapat dibedakan mana yang mempunyai kinerja baik dan tidak. Fokus yang dijadikan subjek penelitian adalah karyawan kontrak, dimana karyawan tersebut yang melakukan pekerjaannya lebih banyak dilapangan daripada di kantor. Tentunya kondisi dari berbagai lingkungan yang terdapat dilapangan mereka sudah merasakan dan sejauh mana karyawan tersebut terdorong dari dirinya sendiri untuk melakukan tugas-tugas yang dibebankannya. Tidak menuntut kemungkinan karyawan tersebut mengalami titik jenuh. Pada tingkat yang seperti ini karyawan akan cenderung meninggalkan pekerjaanya. Hal tersebut bisa dilihat tingkat komitmen karyawan pada organisasi yang semakin menurun meskipun dorongan yang ada pada dirinya untuk tetap melakukan tugas-tugasnya masih tinggi. Jadi yang menjadi permasalahan adalah tentang kondisi lingkungan pekerjaan yang baik namun tidak menjamin tingkat komitmen karyawan pada organisasi tinggi, namun jika dilihat dorongan dari dalam diri karyawan yang tetap tinggi sehingga nanti dapat menjaga komitmen karyawan pada organisasi.

\section{Kajian Teori \\ Kondisi Lingkungan Pekerjaan}

Lingkungan pekerjaan mencakup semua keadaan atau tempat yang ada dalam sebuah organisasi. Kondisi lingkungan tidak semua berbentuk fisik, namun ada juga yang non fisik seperti hubungan antar karyawan (Nitisemito, 2002; Sedarmayanti, 2011). Kondisi lingkungan pekerjaan menunjukkan kondisi dimana tempat kerja seseorang, baik kondisi fisik maupun non fisik. Kondisi yang menyangkut karyawan di bagian lapangan indikator yang digunakan meliputi suhu udara, suara bising, keamanan kerja dan hubungan antar karyawan (Sedarmayanti, 2011).

Kondisi lingkungan pekerjaan dalam beberapa kajian menjelaskan bahwa memiliki peran penting dalam mendorong seorang karyawan dalam melakukan tugas yang telah dibebankan (Neill dan Mclarnon, 2017). Namun terdapat juga kajian yang sebaliknya, kondisi lingkungan pekerjaan kurang memiliki peranan penting dalam mendorong seseorang untuk melakukan pekerjaanya (Sulistyan, 2017). Dari hasil kajian tersebut dapat disimpulkan bahwa kondisi lingkungan pekerjaan khususnya karyawan lapangan masih terdapat gap hubungannya dalam mendorong karyawan tersebut untuk tetap tinggi.

\section{Dorongan dari dalam}

Dorongan dari dalam diri seseorang merupakan salah satu dari dimensi motivasi. Dorongan ini timbul dari dalam diri seseorang yang diakibatkan oleh suatu faktor (Sutrisno, 2017). Dorongan dari dalam diri karyawan bentuknya dapat berupa adanya sesuatu yang memang ingin diketahui oleh karyawan tersebut. Bisa juga karena adanya sesuatu hal yang baru atau bisa juga karena karyawan mempunyai keinginan sesuatu hal yang berbeda dari karyawan lain (Sulistyan, 2017).

Dorongan yang terdapat dalam diri karyawan memiliki peran penting dalam membentuk kesetiaan karyawan tersebut kepada organisasi. Karyawan yang memang sudah terdorong dari dalam dirinya, kemungkinan besar akan berkomitmen kepada organisasinya (James dan Simmons, 2007; Mattson et al., 2014; Katz, 2015). Disisi lain disebutkan bahwa terdapatnya keseimbangan yang diberikan kepada karyawan sebagai balas jasa atas apa yang telah diberikan kepada karyawan 
dapat mendorong karyawan untuk tetap berkomitmen kepada organisasi dimana tempat kerjanya (Azem dan Akhtar, 2014).

\section{Komitmen Karyawan}

Komitmen karyawan merupakan ikatan secara psikologis seorang karyawan pada organisasi ditandai dengan adanya kepercayaan pada tujuan organisasi, adanya kemauan berusaha dengan sungguh-sungguh dan keinginan untuk tetap setia dan memelihara keanggotaannya dalam organisasi. Komitmen karyawan kepada organisasi sebagai bukti kesetiaan karyawan dan juga diimbangi dengan hasil kerja yang baik. Adanya keterikatan karyawan secara emosional kepada organisasi juga salah satu bentuk komitmen karyawan (Luthans, 2002; Robbis, 2015).

Kondisi lingkungan yang menyangkut hubungan dengan sesama karyawan, seperti adanya konflik nantinya akan mempengaruhi tingkat psikologi dan dorongan dari dalam diri karyawan untuk tetap berkomitmen menurun (Neill dan Mclarnon, 2017). Beberapa kajian terkait dengan kondisi lingkungan pekerjaan justru sebaliknya yakni dapat mendorong seseorang dari dalam dirinya. Tidak hanya dalam bentuk imbalan atas apa yang telah dihasilkan, tetapi kondisi dari lingkungan pekerjaan juga dapat mendorong seseorang untuk tetap tinggal di sebuah organisasi (James dan Simmons, 2007; Mattson et al., 2014; Katz, 2015).

\section{Kerangka Konseptual}

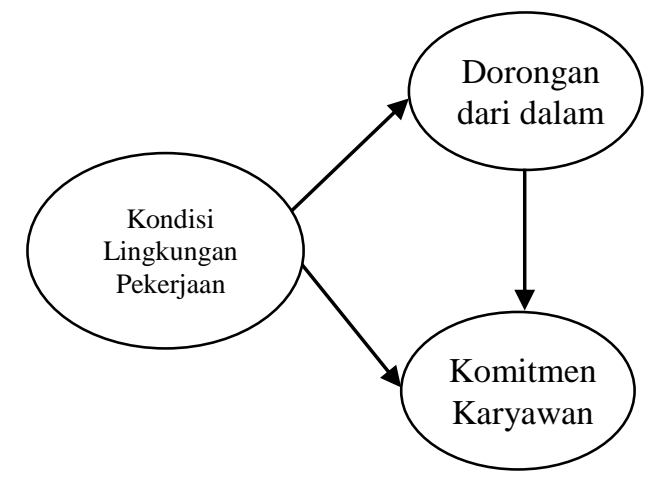

Gambar 1. Kerangka Konseptual

Gambar 1 di atas mengilustrasikan model dalam penelitian ini, menunjukkan bahwa komitmen karyawan kepada organisasi dapat dipengaruhi oleh dua faktor yaitu kondisi lingkungan pekerjaan dan dorongan dari dalam diri karyawan. Selain itu dorongan dari dalam diri karyawan juga dapat dipengaruhi oleh kondisi lingkungan pekerjaan karyawan tersebut. Oleh karena itu hipotesis dalam penelitian ini disusun sebagai berikut:

H1 Kondisi lingkungan pekerjaan

= yang baik dapat mendorong karyawan dari dalam dirinya.

$\mathrm{H} 2$ Kondisi lingkungan pekerjaan

= yang baik dapat meningkatkan komitmen karyawan kepada organisasi.

H3 Dorongan yang terdapat pada diri

$=$ karyawan dapat meningkatkan komitmen karyawan pada organisasi.

H4 Kondisi lingkungan pekerjaan

= yang baik dapat mendorong karyawan dari dalam dirinya dan akan meningkatkan komitmen karyawan pada organisasi.

\section{Metode Penelitian}

Populasi yang menjadi target dalam penelitian ini adalah karyawan kontrak yang ada di lapangan pada UPT. PSDA di Lumajang, baik yang terdapat di Kabupaten Lumajang maupun di Kabupaten Jember. Selama penelitian, digunakan metode sampel sensus yakni semua anggota populasi dijadikan sebagai sampel dan diperoleh sampel sebanyak 41 responden. Teknik pengumpulan data berupa observasi terkait dengan kondisi lingkungan, dorongan untuk melaksanakan tugas dan kesetiaannya atau komitmen 
karyawan pada organisasi. Kuesioner didistribusikan secara pribadi kepada responden. Wawancara digunakan sebagai pendukung hasil penelitian.

Pendekatan yang digunakan dalam penelitian ini adalah Partial Least Square (PLS). Hipotesis diuji dalam pemodelan persamaan struktural atau inner model dan model pengukuran atau outer model. Inner model menunjukkan hubungan antar variabel laten. Di dalam inner model ada dua variabel yaitu variabel laten dependen dan independen. Outer model menggambarkan hubungan antara variabel dengan indikator. Terdapat juga error yaitu variasi dari variabel yang tidak dijelaskan dalam model (Widarjono, 2015). Dianalisis dengan menggunakan metode PLS melalui Software SmartPLS.

\section{Hasil dan Pembahasan Hasil Analisis Data}

Dari seluruh karyawan kontrak yang dijadikan responden dengan jumlah 41 orang, dapat diklasifikasikan berdasarkan jenis kelamin, masa kerja, usia, status perkawinan dan tingkat pendidikan. Keseluruhan karyawan adalah jenis kelamin laki-laki. Sebesar 58,54 persen karyawan dengan masa kerja lima sampai sepuluh tahun dan sebesar 41,46 persen karyawan dengan masa kerja di atas sepuluh tahun. Tidak ada karyawan yang bekerja lebih dari sepuluh tahun. Dilihat dari usia karyawan cukup variatif dan didominasi karyawan yang berusia tiga puluh sampai tiga puluh lima tahun. Status perkawinan karyawan sebesar 87,80 persen dan selebihnya belum kawin. Dari tingkat pendidikan karyawan ratarata SMA atau sederajat.

Tabel 1. Average Variance Extracted (AVE), Composite Reliability (CR), Mean dan Alpha Cronbach

\begin{tabular}{l|c|c|c|c|c|c}
\hline & $\mathrm{VE}$ & $\mathrm{R}$ & an & & & \\
\hline 1. Kondisi & 0.5 & 0.8 & 3.5 & 0.6 & & \\
Lingkungan & 02 & 01 & 79 & 91 & & \\
Pekerjaan & & & & $*$ & & \\
2. Dorongan & 0.5 & 0.7 & 4.0 & 0.5 & 0.6 & \\
dari dalam diri & 50 & 84 & 89 & 62 & 19 & \\
3. Komitmen & 0.7 & 0.8 & 4.0 & 0.5 & 0.6 & 0.8 \\
Karyawan & 06 & 78 & 08 & 84 & 22 & 07 \\
& & & & & & $*$ \\
\hline
\end{tabular}

Catatan: *Alpha cronbach

Sumber: Data diolah 2018

Tabel 1 menunjukkan nilai dari Average Variance Extracted (AVE), Composite Reliability (CR), Mean dan Alpha Cronbach. Nilai AVE dari seluruh variabel di atas 0.50 yang berarti bahwa masing-masing variabel memenuhi asumsi validitas. Hasil juga menunjukkan nilai $\mathrm{CR}$ masing-massing variabel yaitu $0.801,0.784$ dan 0.878 . Hasil pengujian reliabilitas menunjukkan nilai dari masing-masing variabel yaitu, 0.679 untuk kondisi lingkungan pekerjaan, 0.610 untuk dorongan dari dalam, dan 0.796 untuk komitmen karyawan. Dari hasil tersebut jelas bahwa nilai reliabilitas untuk masing-masing variabel di atas 0.60 dan dapat disimpulkan bahwa seluruh variabel yang diteliti mempunyai tingkat reliabilitas yang baik dan dapat dierima dengan jelas.

Pada tabel 2 dapat dilihat hasil dari kondisi lingkungan pekerjaan bahwa indikator suhu udara menjadi faktor utama. Dorongan dari dalam diri karyawan menunjukkan bahwa indikatornya berupa kepedulian adalah faktor yang utama. Komitmen karyawan yang menjadi faktor utama adalah indikator kontinyu.

Tabel 2. Outer Loadings

\begin{tabular}{c|l|c}
\hline \multicolumn{1}{c|}{ Variabel } & \multicolumn{1}{|c|}{ Indikator } & $\begin{array}{c}\text { Outer } \\
\text { Loadings }\end{array}$ \\
\hline \multirow{4}{*}{$\begin{array}{l}\text { Kondisi } \\
\text { lingkungan } \\
\text { pekerjaan }\end{array}$} & Suhu udara & 0.730 \\
\cline { 2 - 3 } & Suara bising & 0.658 \\
\cline { 2 - 3 } & $\begin{array}{l}\text { Keamanan } \\
\text { kerja }\end{array}$ & 0.721 \\
\cline { 2 - 3 } & $\begin{array}{l}\text { Hubungan } \\
\text { antar karyawan }\end{array}$ & 0.723 \\
\hline
\end{tabular}




\begin{tabular}{l|l|l}
\hline \multirow{2}{*}{$\begin{array}{l}\text { Dorongan dari } \\
\text { dalam diri }\end{array}$} & Kepedulian & 0.727 \\
\cline { 2 - 3 } & Kesempatan & 0.663 \\
\cline { 2 - 3 } & Minat & 0.826 \\
\hline \multirow{2}{*}{$\begin{array}{l}\text { Komitmen } \\
\text { karyawan }\end{array}$} & Afektif & 0.815 \\
\cline { 2 - 3 } & Kontinyu & 0.896 \\
\cline { 2 - 3 } & Normatif & 0.806 \\
\hline
\end{tabular}

Sumber: Data diolah 2018

Analisis data dalam penelitian ini menggunakan metode Partial Least Square (PLS). Nilai koefisien beta pada pengaruh langsung dan tidak langsung dalam penelitian ini disajikan pada tabel 2 .

Tabel 2. Pengaruh langsung dan tidak langsung

\begin{tabular}{|c|c|c|}
\hline $\begin{array}{c}\text { Hubungan antar } \\
\text { variabel }\end{array}$ & $\begin{array}{l}\text { Pengaruh } \\
\text { langsung }\end{array}$ & $\begin{array}{l}\text { Pengaruh } \\
\text { tidak } \\
\text { langsung }\end{array}$ \\
\hline $\begin{array}{l}\text { 1. Kondisi } \\
\text { lingkungan } \\
\text { pekerjaan } \rightarrow \\
\text { Dorongan } \\
\text { dari dalam } \\
\text { diri }\end{array}$ & 0.562 & \\
\hline $\begin{array}{l}\text { 2. } \begin{array}{l}\text { Dorongan } \\
\text { dari dalam }\end{array} \\
\text { diri } \rightarrow \\
\text { Komitmen } \\
\text { Karyawan }\end{array}$ & 0.429 & \\
\hline $\begin{array}{l}\text { 3. Kondisi } \\
\text { lingkungan } \\
\text { pekerjaan } \rightarrow \\
\text { Dorongan } \\
\text { dari dalam } \\
\text { diri } \rightarrow \\
\text { Komitmen } \\
\text { karyawan }\end{array}$ & & 0.241 \\
\hline
\end{tabular}

Sumber: Data diolah 2018

Dari keseluruhan hipotesis yang diajukan dan di analisis dengan menggunakan metode Partial Least Square (PLS) menunjukkan bahwa keseluruhan hipotesis diterima. Secara ringkas disajikan pada tabel 3 sebagai berikut:

Tabel 3. Hasil pengujian hipotesis

\begin{tabular}{cll|c}
\hline \multicolumn{3}{c|}{ Hipotesis } & Hasil \\
\hline H1 & Kondisi lingkungan & \\
$:$ & pekerjaan yang baik dapat & Diterima \\
& mendorong karyawan dari & \\
dalam dirinya & \\
\hline
\end{tabular}

\begin{tabular}{|c|c|c|}
\hline $\begin{array}{c}\mathrm{H} 2 \\
:\end{array}$ & $\begin{array}{lr}\text { Kondisi } & \text { lingkungan } \\
\text { pekerjaan yang baik dapat } \\
\text { meningkatkan } & \text { komitmen } \\
\text { karyawan pada organisasi }\end{array}$ & Diterima \\
\hline $\begin{array}{c}\mathrm{H} 3 \\
:\end{array}$ & $\begin{array}{l}\text { Dorongan yang terdapat } \\
\text { pada diri karyawan dapat } \\
\text { meningkatkan komitmen } \\
\text { karyawan pada organisasi }\end{array}$ & Diterima \\
\hline $\begin{array}{c}\mathrm{H} 4 \\
:\end{array}$ & $\begin{array}{l}\text { Kondisi lingkungan } \\
\text { pekerjaan yang baik dapat } \\
\text { mendorong karyawan dari } \\
\text { dalam dirinya dan akan } \\
\text { meningkatkan komitmen } \\
\text { karyawan pada organisasi }\end{array}$ & Diterima \\
\hline
\end{tabular}

Sumber: Data diolah 2018

\section{Pembahasan}

Kondisi lingkungan pekerjaan yang baik dapat mendorong karyawan dari dalam dirinya

Adanya kondisi lingkungan pekerjaan yang baik ternyata dapat mendorong seorang karyawan dari dirinya. Penilaian persepsi yang tinggi dari karyawan kontrak yang ada di lapangan UPT. PSDA di Lumajang terhadap keseluruhan indikator dari kondisi lingkungan pekerjaan mempunyai pengaruh yang signifikan terhadap dorongan dari dalam diri karyawan tersebut. Hasil kajian ini mendukung dari pendapat Nitisemito (2002) dan Sedarmayanti (2011) serta penelitian yang dilakukan oleh Neill dan Mclarnon (2017). Namun hasil ini tidak mendukung hasil penelitian yang dilakukan Sulistyan (2017).

Karyawan yang ada di lapangan merasa bahwa lingkungan pekerjaan ditunjukkan dengan beberapa indikator dan terdapat prioritas-prioritas dalam mempersepsikannya. Prioritas utama adalah suhu udara yang ada di tempat kerja memudahkan untuk beradaptasi. Prioritas kedua adalah hubungan antar karyawan ditunjukkan dengan adanya hubungan baik antar sesama karyawan sehingga memudahkan kerja sama antar sesama karyawan. Selanjutnya prioritas ketiga yaitu keamanan kerja yang 
ditunjukkan dengan adanya jaminan keamanan kerja sehingga membuat karyawan bersemangat dalam menyelesaikan pekerjaan. Yang menjadi prioritas terakhir adalah suara bising diuraikan dalam terdapatnya suara bising di tempat kerja sehingga memberikan pengaruh yang kurang baik pada pekerjaan.

Kondisi lingkungan pekerjaan dapat mendorong karyawan lapangan dari dalam dirinya karena memang karyawan ini dalam kesehariannya berada di lapangan. Suhu udaha yang berubah-ubah, hubungan antar karyawan yang harmonis, keamanan ditempat kerja dan adanya suara bising, semua ini mereka rasakan setiap hari. Dari sini mereka terbiasa dengan alam disekitar tempat kerjanya, sehingga timbul dorongan-dorongan dari dalam dirinya. Ketika terjadi penyegaran atau pertukaran lokasi pekerjaan, mereka mudah beradaptasi dengan lingkungan sekitar dan ini dapat mendorong dan membuat semangat dari dalam dirinya untuk melaksanakan tugas-tugas yang diberikan.

Kondisi lingkungan pekerjaan yang baik dapat meningkatkan komitmen karyawan pada organisasi

Kondisi lingkungan pekerjaan yang baik juga dapat meningkatkan komitmen karyawan pada organisasi. Dari hasil penilaian persepsi dari karyawan kontrak di lapangan yang ada pada UPT. PSDA di Lumajang terhadap keseluruhan indikator mempunyai pengaruh signifikan terhadap komitmen karyawan pada organisasi tersebut. Hasil penelitian ini mendukung pendapat Luthans (2002) dan Robbis (2015) serta penelitian-penelitian sebelumnya (Neill dan Mclarnon, 2017; James dan Simmons, 2007; Mattson et al., 2014; Katz, 2015).

Meningkatnya komitmen karyawan lapangan pada instansi dapat dilihat dari kondisi lingkungan pekerjaanya yang baik. Ketika terjadi perpindahan lokasi pekerjaan, mereka merasa semakin tertantang untuk menyelesaikan tugastugasnya. Mereka berupaya untuk menjadikan lingkungan pekerjaan sebaik mungkin, sehingga ketika terdapat evaluasi mereka puas dengan apa yang telah dikerjakan dan menjadikan mereka semakin komitmen pada organisasi.

Dorongan yang terdapat dari dalam diri karyawan dapat meningkatkan komitmen karyawan pada organisasi

Dorongan dari dalam diri karyawan kontrak yang ada di lapangan pada UPT. PSDA di Lumajang akan dapat meningkatkan komitmen dari karyawan tersebut. Dorongan dari dalam diri karyawan yang dipersepsikan dari keseluruhan indikator mempunyai pengaruh yang signifikan terhadap komitmen karyawan pada organisasi. Hasil dari penelitian ini mendukung pendapat Sutrisno (2017) serta hasil penelitian yang dilakukan James dan Simmons (2007), Azem dan Akhtar (2014), Mattson et al., (2014), Katz (2015), dan Sulistyan (2017).

Terdapat prioritas dari indikator yang diuraikan dorongan dari dalam diri karyawan. Prioritas yang utama berupa minat yaitu pekerjaan tersebut menarik minat dari karyawan. Dengan adanya minat maka komitmen karyawan akan terbentuk dan akan semakin meningkat. Prioritas kedua yaitu kepedulian yang ditunjukkan dengan terdapatnya kepedulian karyawan dengan pekerjaan. Kepedulian pada pekerjaan menjadi bukti terdapatnya nilai-nilai kesetiaan atua komitmen karyawan pada organisasi. Prioritas terakhir yaitu kesempatan berupa adanya kesempatan untuk belajar sesuatu hal yang baru. Dengan diberinya sebuah kesempatan untuk belajar hal yang baru, karyawan 
yang ada di lapangan semakin berkomitmen dan loyal pada organisasi.

Kondisi lingkungan pekerjaan yang baik dapat mendorong karyawan dari dalam dirinya dan akan meningkatkan komitmen karyawan pada organisasi

Adanya kondisi lingkungan pekerjaan yang baik dapat mendorong karyawan dari dalam dirinya dan dapat meningkatkan komitmen karyawan pada organisasi. Hasil ini mendukung pendapat para ahli dan hasil penelitian sebelumnya. Terdapat prioritas dari beberapa indikator komitmen karyawan pada organisasi. Prioritas utama adalah kontinyu atau berkelanjutan dimana terdapatnya perasaan rugi jika berhenti bekerja pada instansi tersebut. Prioritas kedua adalah afektif berupa adanya perasaan bahagia berkarir pada instansi tersebu. Prioritas terakhir yaitu normatif berupa adanya didikan untuk percaya terhadap nilai tetap setia pada satu instansi.

Dari keseluruhan karyawan yang ada di lapangan adalah berjenis kelamin laki-laki. Mereka memang lebih menyukai jika bekerja di lapangan. Dengan adanya persepsi seperti ini mereka berupaya dan terdorong dari dalam dirinya bagaimana untuk menciptakan kondisi lingkungan yang baik dan terbentuk komitmen yang tinggi. Dilihat dari masa kerja seluruh karyawan lebih dari lima tahun, sebagian besar sudah bersatus menikah dan latar belakang pendidikan SMA. Adanya kesetiaan karyawan pada organisasi ini ditunjukkan dengan masa kerja yang cukup lama dan adanya faktor keluarga dan latar belakang pendidikan yang mejadikan mereka semakin berkomitmen.

\section{Kesimpulan}

Kesimpulan dari penelitian ini berupa adanya kondisi lingkungan pekerjaan yang baik dapat mendorong karyawan dari dalam dirinya. Kondisi lingkungan pekerjaan yang baik dapat meningkatkan komitmen karyawan pada organisasi. Kondisi lingkungan pekerjaan yang baik dapat meningkatkan komitmen karyawan pada organisasi. Kondisi lingkungan pekerjaan yang baik dapat mendorong karyawan dari dalam dirinya dan akan meningkatkan komitmen karyawan pada organisasi. Hasil penelitian ini mendukung seluruh hipotesis yang diajukan.

Terdapat peran dari adanya dorongan dari dalam diri karyawan sebagai upaya menciptakan kondisi lingkungan pekerjaan yang baik dalam meningkatkan komitmen karyawan. Dari hasil ini disumsikan bahwa untuk meningkatkan komitmen karyawan pada organisasi dapat memperhatikan dorongan yang terdapat dalam diri karyawan tersebut sebagai dampak dari adanya kondisi lingkungan pekerjaan yang baik. Hal yang paling penting adalah untuk tetap memperhatikan dorongan yang ada dalam diri karyawan tersebut, karena memberikan dampak paling besar dalam meningkatkan komitmen karyawan. Jika dibandingkan dengan kondisi lingkungan pekerjaan, meskipun terlihat baik tetapi dorongan dari dalam tetap menjadi faktor utama meningkatkan komitmen karyawan pada organisasi.

\section{Daftar Pustaka}

Azeem, S. M., \& Akhtar, N. (2014). The Influence of Work Life Balance and Job Satisfaction on Organizational Commitment of Healthcare Employees. International Journal of Human Resource Studies, 4(2), 18-24. https://doi.org/10.5296/ijhrs.v4i2.5 667 
Driskell, T., Salas, E., \& Driskell, J. E. (2017). Human Resource Management Review Teams in extreme environments : Alterations in team development and teamwork. Human Resource Management Review, 1-16. https://doi.org/10.1016/j.hrmr.2017 .01 .002

Gullekson, N., \& Dumaisnil, A. (2016). Human Resource Management Review Expanding horizons on expatriate adjustment: A look at the role of emotional display and status. Human Resource Management Review. https://doi.org/10.1016/j.hrmr.2016 .03.004

James, W., \& Bret, L. (2007). The Effects of Work Environment on the Personality-Performance. Journal of Managerial Issues. XIX (2), 288-305.

Katz, I. (2015). What makes a motivating teacher? Teachers , motivation and beliefs as predictors of their style. https://doi.org/10.1177/014303431 5609969

Luthans, F. 2002. Organizational Behavior. Singapura: McGraw-Hill Book Co-Singapore.

Mattson, M., Torbiörn, I., \& Hellgren, J. (2014). Human Resource Management Review Effects of staff bonus systems on safety behaviors. Human Resource Management Review, 24(1), 1730.

https://doi.org/10.1016/j.hrmr.2013 .08 .012

Neill, T. A. O., \& Mclarnon, M. M. J. W. (2017). Human Resource Management Review Optimizing team con fl ict dynamics for high performance teamwork. Human
Resource Management Review, (June), 0-1. https://doi.org/10.1016/j.hrmr.2017 .06 .002

Nitisemito, S, A. (2002). Manajemen Personalia: Manajemen Sumebr Daya Manusia. Jakarta: Ghalia Indonesia.

Robbins, Stephen P. (2015). Perilaku Organisasi. Jakarta: Salemba Empat.

Sedarmayanti. (2011). Tata Kerja dan Produktivititas Kerja, suatu tinjauan dari aspek ergoekonomi atau kaitan antara manusia dengan lingkungan kerjanya. Bandung: C. Mandar Maju.

Sulistyan, R. B. (2017). Contribution Of Leadership And Environmental Work In Improving Employee Motivation. Jurnal Ilmu Manajemen Advantage, 1(2), 166177.

Sutrisno, Edy. (2017). Manajemen Sumber Daya Manusia. Jakarta: Prenadamedia Group

Ushie, E. M., Ogaboh, A. A. M., \& Okorie, C. (2015). Work Environment and Employees' Commitment in AgroBasedIndustries in Cross River State, Nigeria, 15(6).

Waldkirch, M., Nordqvist, M., \& Melin, L. (2017). Human Resource Management Review CEO turnover in family fi rms: How social exchange relationships in $\mathrm{fl}$ uence whether a non-family CEO stays or leaves. Human Resource Management Review, (xxxx), 0-1. https://doi.org/10.1016/j.hrmr.2017 .05 .006 .

Widarjono, Agus. (2015). Analisis Multivariat Terapan dengan Program SPSS, AMOS dan 
SMART PLS. Yogyakarta: UPP STIM YKPN. 